\title{
Heavy Metals (Cd, Pb, and Zn) Residue in Selected Tissue and Organs of Slaughtered Goat-Meat randomly selected from Markets in Ayegbaju-Ekiti, Akure, and Owena
}

\author{
Adedayo Olamide Oyebanji ${ }^{1(\mathbb{D})}$, Daniel Uwaremhevho Momodu ${ }^{2^{*}(\mathbb{D})}$, Toluwase Hezekiah Fatoki ${ }^{2}$ (D) and \\ Victoria Jumoke Alabi ${ }^{1}$ (D) \\ 1 Department of Chemical Sciences, Joseph Ayo Babalola University, Ikeji Arakeji, Osun State, Nigeria \\ 2 Department of Chemistry, Faculty of Science, Federal University Oye-Ekiti, Ekiti State, Nigeria \\ * Correspondence: daniel.momodu@ fuoye.edu.ng;
}

Received: 16.08.2020; Revised: 22.09.2020; Accepted: 26.09.2020; Published: 3.10.2020

\begin{abstract}
This study investigated Cadmium (Cd), Lead (Pb), and Zinc ( $\mathrm{Zn}$ ) content of some selected organs (liver, kidney, heart, and intestine) and tissue (blood) of slaughtered goats randomly sampled from central markets in Ayegbaju-Ekiti, Akure and Owena, South-western Nigeria. Atomic Absorption Spectrophotometer (AAS) was used to determine the level of heavy metals based on comparison with standards. The mean concentrations obtained $\mathrm{Zn}$ were detected in all samples investigated, but $\mathrm{Cd}$ was undetected in some samples, especially the liver and blood of goat from Owena. The general trend in the mean concentration of metals was $\mathrm{Zn}>\mathrm{Pb}>\mathrm{Cd}$, in tissue and organs was kidney $>$ liver $>$ intestine $>$ heart > blood, and in-market, with respect to metals, was Akure > Ayegbaju-Ekiti=Owena for Cd, Ayegbaju-Ekiti > Akure > Owena for $\mathrm{Pb}$ and Owena $>$ Akure $>$ Ayegbaju-Ekiti for $\mathrm{Zn}$. All the metals

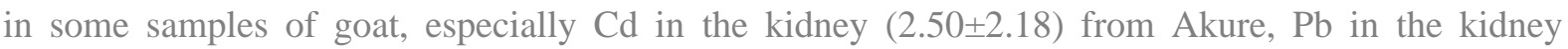
$(19.00 \pm 9.17 \mathrm{mg} / \mathrm{kg})$ from Ayegbaju-Ekiti and intestine $(15.00 \pm 17.35 \mathrm{mg} / \mathrm{kg}$ ) from Akure as well as Zn in the heart $(71.50 \pm 95.90 \mathrm{mg} / \mathrm{kg})$ from Ayegbaju-Ekiti, had a mean concentration in excess of the permissible limits set by FAO/WHO. Some of the tissue and organs of goats sampled from the studied area were therefore polluted with all the metals investigated, and their consumption may have health implications.
\end{abstract}

Keywords: heavy metals; goat; organ; tissue and market.

(C) 2020 by the authors. This article is an open-access article distributed under the terms and conditions of the Creative Commons Attribution (CC BY) license (https://creativecommons.org/licenses/by/4.0/).

\section{Introduction}

Heavy metals make a significant contribution to environmental pollution as a result of anthropogenic activities such as mining, energy and fuel production, power transmission, intensive agricultural practices, sludge, and industrial effluent discharge as well as military operations [1]. These metals are natural components of the environment, but the high rate of industrialization has been responsible for their wider diffusion and dispersal in the environment [2]. Metal salts have been used therapeutically in human and veterinary medicine for centuries; however, humans and animals are now exposed to more metals than they were previously. Metals for which there are no nutritional requirements may interfere with biological systems, causing adverse effects [3].

Singeing off the hairs of animals in flame fuelled by wood or charcoal mixed with used engine oil, damaged plastics mixed with refuse, or tires is a common practice [4]. During the 
singeing process, a flame from these materials may contain toxic substances such as heavy metals that can contaminate the meat and render it unsuitable for human consumption [5]. In some cases, feeding of the animals with feed contaminated with heavy metal and allowing livestock to graze and drink in areas with a history of mining was reportedly responsible for heavy metal contamination in meat [6]. Among the various possible ways of human exposure to pollutants, food consumption has been rated about $90 \%$, compared with inhalation and dermal contact [7]. Hence, the level of heavy metals in meat is to be given special consideration due to food safety issues and potential health risks. This is because even at relatively low concentrations in nature, heavy metals are harmful [8].

Meat is an important constituent of the food consumed usually because of the protein, fat, and other essential nutrient derived from it [4]. A study by [9] also revealed meat as a good source of niacin, vitamins B6 and B12, phosphorous, zinc, and iron. Animal proteins are known to possess high biological value, and the presence of essential amino acids in them makes a complete protein [10]. Meat and products from meat have also been noticed to be a medium through which certain toxic substances get into the human body [4]. Sources such as animal drugs, pesticides, feed, and other agricultural or industrial chemical substances have been major ways these toxic substances get into meat tissues for human consumption [6]. Several scientific reports have been given on the heavy metals contamination of meat in the form of tissues or organs as a result of the grave danger caused by the bio-accumulation of this metal in the human body. [8] reported various cases of meat product contamination with heavy metals resulting from meat processing. Also, [11] reported high levels of some toxic and trace metals in calves and kids from a polluted area of Northern Spain. [12] investigated $\mathrm{Pb}, \mathrm{Cd}$, and $\mathrm{Zn}$ present in selected tissues and organs of cattle from a central abattoir in some South-western States in Nigeria. [13] also reported high levels of cadmium and led in the blood of cows allowed to graze openly in fields in Nigeria.

Livestock plays a very important role in global agriculture. In Nigeria, the contribution of livestock has been rounded up to about $12.7 \%$ of the total gross domestic product [14]. Nigeria is one of the four leading livestock producers in sub-Sahara Africa. The population of ruminant livestock in Nigeria has been estimated to about 14 million cattle, 13 million sheep, and 23 million goats. However, these figures have since increased to 15.2 million cattle, 28 million goats, and 23 million sheep $[15,16]$. The commonly practiced method of managing livestock in areas within which this research was carried out remains the free-ranging. In this method of livestock management, the animals are allowed to move from place to place in search of food. Hence, it can pick up toxic substances such as heavy metals around major highways caused by emissions from vehicles, scrap-yards, refuge dumps, drinking polluted water from drains and streams, and intake of atmospheric depositions, especially burning with the direct release of fumes without incinerators [3].

Bioaccumulation of heavy metals is reported to be more in the liver, kidney, blood, heart, and intestine than in other organs [8]. However, as a result of the concentration of essential nutrients in these organs, many local people in Nigeria prepare special delicacies such as white soup, "Ngwo Ngwo" in the Igbo language, "Inu Eran" in the Yoruba language, and "Kayan Chiki" in the Hausa language with them [2]. This study was therefore aimed at determining the concentration of heavy metals $(\mathrm{Cd}, \mathrm{Pb}$, and $\mathrm{Zn})$ in some tissue and organs of goat randomly obtained from selected markets in Ekiti, Ondo, and the Osun States of Nigeria. 


\section{Materials and Methods}

\subsection{Materials}

Analytical balance, digestion flask, Bunsen burner, heating mantle, fume chamber, funnels, digestion tubes, nitric acid $\left(\mathrm{HNO}_{3}\right)$, sulphuric acid $\left(\mathrm{H}_{2} \mathrm{SO}_{4}\right)$, distilled water, aluminum foil, spatula, gloves and Whatman grade II filter papers, transparent polyethene bag, pre-treated sample bottles, and glassware.

\subsection{Sample collection.}

Samples were collected from three (3) towns, which are Ayegbaju-Ekiti (Ekiti State), Akure (Ondo State), and Owena (Osun State). Five (5) parts collected from each slaughtered goat are heart, liver, intestine, kidney, and blood. The samples were immediately transferred into polythene bags and transported to the laboratory in an ice bath for digestion and elemental analysis. Quality control measures were observed from the point of materials collection, sample collection, and sample preparation through to the point of sample analysis so as to reduce interference due to contamination by external metallic sources.

\subsection{Sample preparation.}

\subsubsection{Solid sample preparation.}

The tissue and organs of the goat (liver, kidney, heart, and intestine) were diced into bits and dried in the oven for three days at a temperature of $105^{\circ} \mathrm{C}$. They were thereafter ground into a fine powder using a porcelain mortar and pistol. Distilled water $(10 \mathrm{~mL})$ was added to 1 $\mathrm{g}$ of the well ground sample in a $50 \mathrm{~mL}$ beaker followed by $10 \mathrm{~mL} \mathrm{HNO}$. The mixture was boiled at $150{ }^{\circ} \mathrm{C}$ on an electric plate for 100 minutes. When the sample had changed from being a colloidal solution to a clear one, it was cooled, and concentrated $\mathrm{H}_{2} \mathrm{SO}_{4}(5 \mathrm{~mL})$ was added. The mixture was heated at a temperature of $200{ }^{\circ} \mathrm{C}$ for 30 minutes until a dense white fume of the concentrated $\mathrm{H}_{2} \mathrm{SO}_{4}$ was noticed. The solution was then allowed to cool and transferred quantitatively into a $50 \mathrm{ml}$ standard flask by filtering using a No.1 $110 \mathrm{~mm}$ Whatman filter paper. The filtrate in the standard flask was made up to mark and finally transferred into a labeled sample bottle.

\subsubsection{Liquid sample preparation.}

A solution of $\mathrm{HNO}_{3}$ and $\mathrm{H}_{2} \mathrm{SO}_{4}$ was prepared in the ratio 20:1. The blood (1.5 mL) was measured into a $50 \mathrm{~mL}$ beaker, and $0.5 \mathrm{~mL}$ of the mixture of acids added, followed by $10 \mathrm{~mL}$ distilled water. All these were immediately thoroughly mixed by swirling. The mixture was then heated in a water bath at $60{ }^{\circ} \mathrm{C}$ until the original volume was reduced to half. Nitric acid $(1 \mathrm{~mL})$ was then added to the reduced solution, and heating continued until the solution became clear. This was then cooled and filtered into a $50 \mathrm{~mL}$ standard flask using a No.1 $110 \mathrm{~mm}$ Whatman filter paper. It was made up to the mark with distilled water and transferred into a labeled sample bottle.

\subsection{Sample analysis.}

The concentration of heavy metals in solutions of blank, standard, and digested samples were determined using BUCK Scientific 210 VGP Atomic Absorption Spectrophotometer 
(AAS) at machine conditions contained in the instruction manual and wavelengths of 283.2 $\mathrm{nm}, 228.9 \mathrm{~nm}, 213.9 \mathrm{~nm}$ for lead, cadmium, and zinc respectively.

\subsection{Statistical analysis.}

Data were taken in triplicate and analyzed using Microsoft Excel Version 2010. The results were expressed as mean and standard deviation. Graphpad prism Version 6.0 was used for the graphical plot.

\section{Results and Discussion}

Figures 1, 2, and 3 show the respective concentration (mean \pm standard deviation) of $\mathrm{Cd}$, $\mathrm{Pb}$, and $\mathrm{Zn}$ in the blood, kidney, heart, intestine, and liver of slaughtered goats from AyegbajuEkiti, Akure, and Owena Markets and the permissible level set by Food and Agricultural Organisation and World Health Organisation (FAO/WHO) (2000).

\section{Cd}

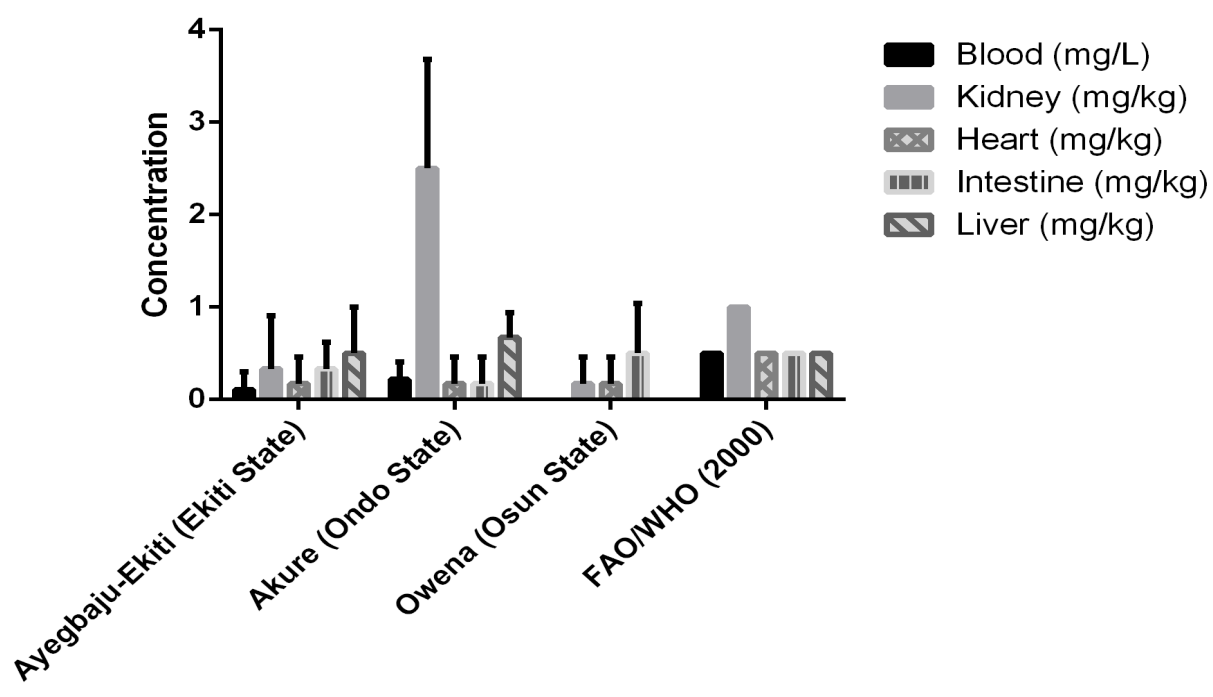

Figure 1. Concentration of Cd in goat's part for FAO/WHO (2000) and this study.

$\mathrm{Pb}$

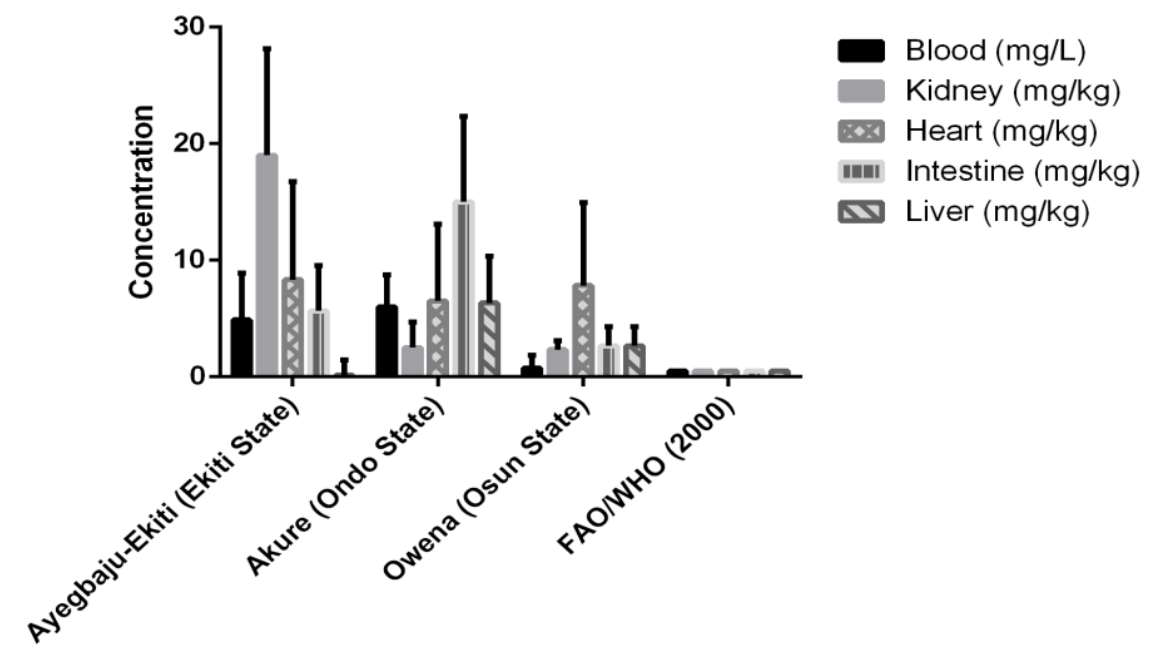

Figure 2. Concentration of $\mathrm{Pb}$ in goat's part for FAO/WHO (2000) and this study. 


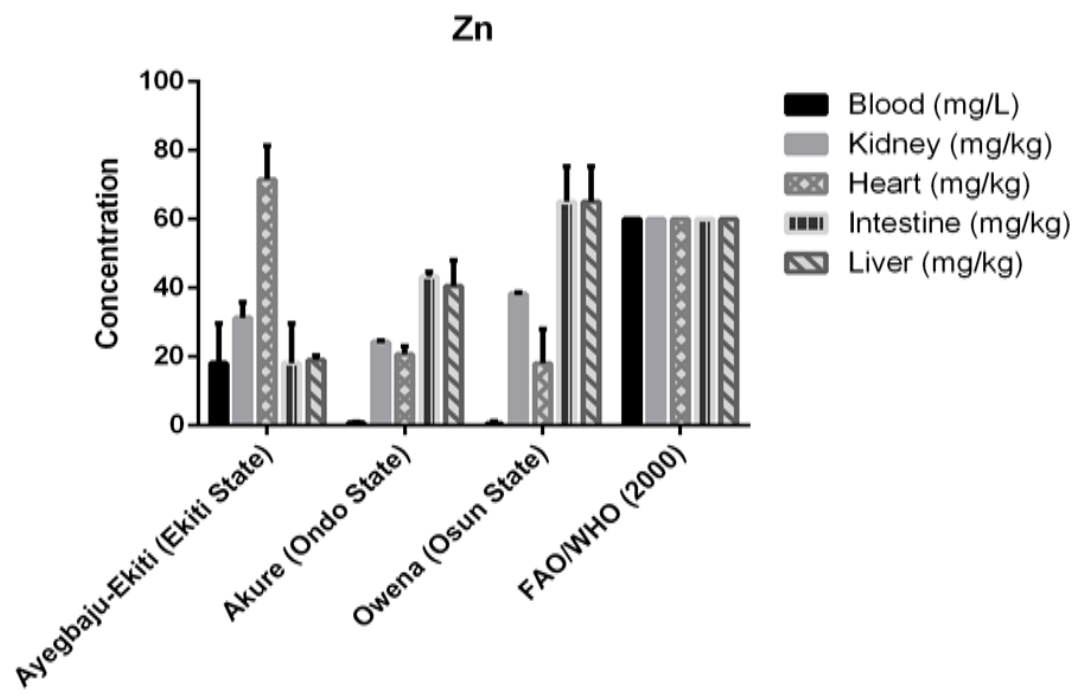

Figure 3. Concentration of $\mathrm{Zn}$ in goat's part for FAO/WHO (2000) and this study.

\subsection{Discussion.}

The results presented in Figures 1-3 above show a clear trend in the distribution of heavy metals in the samples of the slaughtered goats. In general, the trend observed for the metals was $\mathrm{Zn}>\mathrm{Pb}>\mathrm{Cd}$ and for the tissue and organs was kidney $>$ liver $>$ intestine $>$ hear $\mathrm{t}>$ blood. With respect to the markets, the trend for $\mathrm{Cd}$ was Akure > Ayegbaju-Ekiti=Owena, for $\mathrm{Pb}$ Ayegbaju-Ekiti > Akure > Owena, and for Zn Owena > Akure > Ayegbaju-Ekiti. Moreover, $\mathrm{Cd}$ was the most undetected metal in the samples, especially in the blood and liver of the goat from Owena. Where detected, Cd means concentration ranged from $0.11-2.50 \mathrm{mg} / \mathrm{kg}$, the lower limit being in the blood of goat from Ayegbaju-Ekiti, and the upper in the kidney of goat sampled at Akure. Unlike $\mathrm{Cd}, \mathrm{Pb}$ was detected in all the samples investigated. Its minimum mean concentration $(0.17 \mathrm{mg} / \mathrm{kg})$ was observed in the liver of goat from Ayegbaju-Ekiti, and its maximum $(19.00 \mathrm{mg} / \mathrm{kg}$ ) was obtained in the kidney of goat from Ayegbaju-Ekiti. Like Pb, $\mathrm{Zn}$ was detected in all the samples, and its mean concentration ranged from $0.45 \mathrm{mg} / \mathrm{kg}$ in the blood of goat sampled from Owena to $71.50 \mathrm{mg} / \mathrm{kg}$ obtained in the heart of the goat sampled from Ayegbaju-Ekiti. Also, Table 1 shows the guideline for $\mathrm{Cd}, \mathrm{Pb}$, and $\mathrm{Zn}$ in the goat set by Food and Agriculture Organization (FAO)/World Health Organization (WHO) (2000).

Table 1. International standard guideline for cadmium, lead, and zinc in goat.

\begin{tabular}{l|l|l|l} 
Sample type & Cd & Pb & Zn \\
\hline Blood & $0.50 \mathrm{mg} / \mathrm{L}$ & $0.50 \mathrm{mg} / \mathrm{L}$ & $60 \mathrm{mg} / \mathrm{L}$ \\
\hline Kidney & $1.00 \mathrm{mg} / \mathrm{kg}$ & $0.50 \mathrm{mg} / \mathrm{kg}$ & $60 \mathrm{mg} / \mathrm{kg}$ \\
\hline Liver & $0.50 \mathrm{mg} / \mathrm{kg}$ & $0.50 \mathrm{mg} / \mathrm{kg}$ & $60 \mathrm{mg} / \mathrm{kg}$ \\
\hline Heart & $0.50 \mathrm{mg} / \mathrm{kg}$ & $0.50 \mathrm{mg} / \mathrm{kg}$ & $60 \mathrm{mg} / \mathrm{kg}$ \\
\hline Intestine & $0.50 \mathrm{mg} / \mathrm{kg}$ & $0.50 \mathrm{mg} / \mathrm{kg}$ & $60 \mathrm{mg} / \mathrm{kg}$
\end{tabular}

(FAO/WHO, 2006)

From Figure 1, Cd was detected in the kidney of goat from Akure $(2.50 \pm 1.18 \mathrm{mg} / \mathrm{kg})$, liver of goat from Ayegbaju-Ekiti $(0.50 \pm 0.50 \mathrm{mg} / \mathrm{kg})$, and liver of goat from Akure $(0.67 \pm 0.27$ $\mathrm{mg} / \mathrm{kg}$ ) but not in the blood and liver of goat from Owena. High level of Cd observed in the kidney of goat from Akure agrees with similar studies which have shown that cadmium bioaccumulates more in the kidney than in other parts of the body $[17,12]$ and [18] have reported higher concentration of cadmium in the kidney than in the liver of free grazing cattle 
from abattoirs situated in seven widely spread localities in Southern Nigeria. Besides, this result agrees with the study by [19] on sheep and horses, which indicated that the kidney has a high affinity for Cd. [20] Previously reported the liver as the target organ for observing metal contamination in animals. Its detoxifying function may also be the reason for the relatively high concentration of cadmium in it [2,3]. It was observed that high Cd levels in goat meat in Nigeria could result from grazing animals, which may expose them to cadmium from atmospheric deposition on grazing pasture. Concentrations of $\mathrm{Cd}$ in the kidney $(2.50 \pm 2.18$ $\mathrm{mg} / \mathrm{kg})$ and in the liver $(0.67 \pm 0.27 \mathrm{mg} / \mathrm{kg})$ of goat from Akure were higher than the respective permissible limits of $0.5 \mathrm{mg} / \mathrm{kg}$ and $1.0 \mathrm{mg} / \mathrm{kg}$ for liver and kidney by FAO/WHO (Table 1 ).

The distribution of $\mathrm{Pb}$ in organs and tissue of goat is shown in Figure $2 . \mathrm{Pb}$ concentration for most samples was above the permissible limit $(0.5 \mathrm{mg} / \mathrm{kg})$ by [15] Concentrations of $\mathrm{Pb}$ in the kidney of goat from Ayegbaju-Ekiti $(19.00 \pm 9.17 \mathrm{mg} / \mathrm{kg}$ ), and intestine of goat from Akure $(15.00 \pm 7.35 \mathrm{mg} / \mathrm{kg})$ was observed to be outrageous. This is similar to the report of [2] in which bioaccumulation of metals in the kidney was high. The transportation of $\mathrm{Pb}$ to these animals may be through direct exposure such as grazing along with major high-ways with appreciably high vehicular emissions or grazing and drinking in areas with a history of mining activities, eating crops grown on sewerage, and possible contact with effluents from industries. The elevated level of $\mathrm{Pb}$ in the intestine of goat from Akure might be because it assimilates digestive end products to the body through the villi. According to [21], it seems as if there is a 'trap' in the intestine that accumulates heavy metals.

Results of $\mathrm{Zn}$ concentration in organ and tissue samples are presented in Figure 3. $\mathrm{Zn}$ was detected at concentrations much higher than lead, and this, in turn, was much higher than cadmium. However, the concentration of $\mathrm{Zn}$ was below the FAO/WHO permissible limit of $60 \mathrm{mg} / \mathrm{kg}$ (Table 1) except for the heart from Ayegbaju-Ekiti $(71.50 \pm 9.90 \mathrm{mg} / \mathrm{kg}$ ), intestine from Owena $(65.00 \pm 10.40 \mathrm{mg} / \mathrm{kg})$, and liver from Owena $(65.00 \pm 10.40 \mathrm{mg} / \mathrm{kg})$. Zinc is an essential element in the human diet. Deficiency of it causes delayed sexual maturation and impaired immune response while excessive intake results in inhibition of copper and iron absorption [22] The concentration of $\mathrm{Zn}$ observed in the heart of goat from Ayegbaju-Ekiti $(71.50 \pm 95.90 \mathrm{mg} / \mathrm{kg})$ was similar to and in agreement with that in goat heart $(71.61 \pm 57.43$ $\mathrm{mg} / \mathrm{kg}$ ) reported by [3].

\section{Conclusions}

This study presents the concentration of cadmium, lead, and zinc in the organs (kidney, heart, liver, and intestine) and the tissue (blood) of slaughtered goats sold at selected markets in Ayegbaju-Ekiti, Akure, and Owena, respectively in Ekiti, Ondo and the Osun States of Nigeria. While cadmium was not detected in the blood and the liver of goat from Owena, lead and zinc were detected in all the samples investigated. The kidney was the organ with the highest level of the three metals investigated while the blood was the least. The concentrations of cadmium observed in the kidney of goat sampled at Akure, lead in the kidney of goat from Ayegbaju-Ekiti and intestine of goat from Akure as well as zinc in the heart of goat from Ayegbaju-Ekiti and the intestine and liver of goat from Owena were all higher than the permissible limits for those metals set by FAO/WHO (2006). Some of the tissue and organs of goats sampled from the studied area were contaminated with the metals investigated at varying degrees, and their consumption may have health implications. 


\section{Funding}

This research received no external funding.

\section{Acknowledgments}

This research has no acknowledgment.

\section{Conflicts of Interest}

The authors declare no conflict of interest.

\section{References}

1. Masindi, V.; Muedi, K.L. Environmental Contamination by Heavy Metals. In: Heavy Metals. Saleh, H. (Ed.), IntechOpen, Croatia, 2018; pp. 115-133, https://doi.org/10.5772/intechopen.76082.

2. Ubwa, S.; Ejiga, R.; Okoye, P.-A.; Amua, Q. Assessment of Heavy Metals in the Blood and Some Selected Entrails of Cows, Goat and Pigs Slaughtered at Wurukum Abattoir, Makurdi-Nigeria. Advances in Analytical Chemistry 2017, 7, 7-12.

3. Okoye, C.O.B.; Ugwu, J.N. Impact of Environmental Cadmium, Lead, Copper and Zinc on Quality of Goat Meat in Nigeria. Bull. Chem. Soc. Ethiop. 2010, 24, 133-138.

4. Nkansah, M.; Ansah, J. Determination of $\mathrm{Cd}, \mathrm{Hg}, \mathrm{As}, \mathrm{Cr}$ and $\mathrm{Pb}$ levels in meat from the Kumasi Central Abattoir. International Journal of Scientific and Research Publications 2014, 4, 1-4.

5. Adam, I.; Teye, M.; Daniel, O. Assessment of Heavy Metal Residues in Hides of Goats Singed with Tyres, and the Effect of Boiling on the Heavy Metal Concentrations in the Hides. Journal of Veterinary Advances 2013, 3, 165-169, https://doi.org/10.5455/jva.20130531104440.

6. Khalafalla, F.A.; Ali, F.H.; Schwagele, F.; Abd-El-Wahab, M.A. Heavy metal residues in beef carcasses in Beni-Suef abattoir, Egypt. Veterinaria italiana 2011, 47, 351-361.

7. Zou, X.; Zhang, K.; Sun, Z.; Zeng, X.; Bo, E.; Tang, Y. Health risk of Pb, Zn, Cd, Cu and Hg to the general public via food chains. In: Environmental Energy and sustainable Development. Sung, K.; Chen. (eds). Taylor and Francis group, London. 2013.

8. Akan, J.C.; Abdulrahman, F.I.; Sodipo, O.A.; Chiroma, Y.A. Distribution of Heavy Metals in the Liver, Kidney and Meat of Beef, Mutton, Caprine and Chicken from Kasuwan Shanu Market in Maiduguri Metropolis, Borno State. Nigeria Research Journal of Applied Sciences, Engineering and Technology 2010, 2, 743-748.

9. Williams, P. Nutritional composition of red meat. Nutrition \& Dietetics 2007, 64, S113-S119, https://doi.org/10.1111/j.1747-0080.2007.00197.x.

10. Bastin, S. Nutrition Value of Meat. Co-op. Ext. Service University of Kentucky - College of Agric. UK. 2007; pp. 1-3.

11. Miranda, M.; López-Alonso, M.; Castillo, C.; Hernández, J.; Benedito, J.L. Effects of moderate pollution on toxic and trace metal levels in calves from a polluted area of northern Spain. Environment International 2005, 31, 543-548, https://doi.org/10.1016/j.envint.2004.09.025.

12. Momodu, D.; Oyebanji, A. Determination of Heavy Metals in Selected Tissues and Organs of Cattle from Central Abattoir in Ado-Ekiti, Akure and Owena. Asian Journal of Applied Chemistry Research 2019, 4, 17, https://doi.org/10.9734/ajacr/2019/v4i1-230102.

13. Okoye, C.O.B.; Ugwu, J.N.; Ibeto, C.N. Characterisation of rural water resources for potable water supply in some parts of South-eastern Nigeria. J Chem Soc Nigeria. Journal of the Chemical Society of Nigeria 2010, 35, 83-88, https://doi.org/10.1007/s10661-020-08366-3.

14. Nwankpa, N. Sustainable Agricultural Development in Nigeria: A Way Out of Hunger and Poverty. European Journal of Sustainable Development 2017, 6, 175-184, https://doi.org/10.14207/ejsd.2017.v6n4p175.

15. FAO. The Sate of food insecurity in the world. Published in 2006 by the Food and Agriculture Organization of the United Nations. Viale delle Terme di Caracalla, 00153 Rome, Italy. (C FAO; 2006.

16. Lawal-Adebowale, O.A. Dynamics of Ruminant Livestock Management in the Context of the Nigerian Agricultural System. 2012; http://dx.doi.org/10.5772/52923.

17. World Health Organization (WHO). Environmental Health Criteria 1: Mercury. Journal of WHO, Geneva: Volume 7, 1996; pp. 94

18. Milam, C.; Dimas, B.J.; Jang, A.; Eneche, J.E. Determination of some heavy metals in vital organs of cows and bulls at Jimeta Abattoir, Yola, Adamawa State, Nigeria. America Chemical Society Journal 2015, 8, 1-7, https://doi.org/10.9734/acsj/2015/17012. 
19. Adei, E.; Forson-Adaboh, K. Toxic ( $\mathrm{Pb}, \mathrm{Cd}, \mathrm{Hg})$ and essential (Fe, $\mathrm{Cu}, \mathrm{Zn}, \mathrm{Mn}$ ) metal content of liver tissue of some domestic and bush animals in Ghana. Food Additives \& Contaminants: Part B 2008, 1, 100-105, https://doi.org/10.1080/02652030802566319.

20. Swaileh, K.M.; Abdulkhaliq, A.; Hussein, R.M.; Matani, M. Distribution of Toxic Metals in Organs of Local Cattle, Sheep, Goat and Poultry from the West Bank, Palestinian Authority. Bulletin of Environmental Contamination and Toxicology 2009, 83, https://doi.org/10.1007/s00128-009-9704-X.

21. Krajnc, E.I.; Vos, J.G.; Van Logten, M.J. Recent animal studies with regard to cadmium toxicity. In: Health evaluation of heavy metals in infant formula and junior food. Schmidt, E.H.F.; Hilde, B.A.G. 22nd edition. Berlin: Spring. Verlag. 2013; pp. 112-119, https://doi.org/10.5923/j.aac.20170701.02. 